\title{
Selenium nanoparticles in rabbit nutrition. a review
}

\author{
Asmaa S.N. Kassim, A.H.H. Ali, Taghreed A. Marwan, and A.A.A. Abdel-Wareth* \\ Department of Animal and Poultry Production, Faculty of Agriculture, South Valley University, \\ 83523 Qena, Egypt
}

\begin{abstract}
The ability of the animal gut to absorb the trace elements and other nutrients, therefore, improving the growth performance of animals. Nanoparticles of Selenium (Nano-Se) promote growth performance of rabbits and it can act as antioxidants, antibacterial agents, improving the immunity system of the rabbits. Moreover, Se is one of the critical nutritional factors necessary for the normal functioning of the immune system and maintenance of gut health, growth, and organ functions. Numerous studies have demonstrated that a deficiency in Se could lead to serious disruptions in animal performances such as growth, digestion, liver damage, pancreatic fibrosis, cystic ovaries, and thyroid metabolism dysfunction. Furthermore, sufficient Se supplementation in rabbits tends to maintain good health and productive performance. The levels of Se in the rabbit diets vary widely according to dietary ingredients and selenium supplementation, ranging from 0.05 to $2.0 \mathrm{mg} / \mathrm{kg}$ diet. Since there are almost unlimited possibilities concerning the dosage of Se there is still more research needed. This review gives an overview of the mode of action, recommendation levels of Nano-Se, and their effects on growth performance, nutrient digestibility, carcass criteria and blood biochemical of rabbits.
\end{abstract}

Keywords: Nanotechnology; Selenium; Mechanism; Performances; Rabbits

\section{Introduction}

Appropriate animal diet and living environment play a key role in animal health and performance. Thus, optimizing these factors is important for increasing rearing efficiency, which can positively determine the quality of production of rabbit origin. Over the last decade, nanotechnology has received the attention of many researchers due to its promising agricultural and food applications. Nanotechnology provides new solutions in animal nutrient delivery and health protection, and, indeed, it has the large potential to improve animal production systems (Horky et al., 2016). This interest is mainly caused by the unique physicochemical properties of

\footnotetext{
*Corresponding author: A.A.A. Abdel-Wareth

Email: a.wareth@agr.svu.edu.eg

Received: January 19, 2022; Accepted: January 30, 2022;

Published online: January 30, 2022.

(C) Published by South Valley University.

This is an open access article licensed under c)(P)
}

nanoparticles, which refer to their small size (1-100 nm), high stability, hydrophobicity, and large surface area. Nanoparticles can be used as an additional source of trace minerals in the rations which have been found to have many novel properties different from those from other selenium (Se) sources (Mohapatra et al., 2014). Dietary Se is an essential trace element for animal growth, immunity, hormones, fertility, biochemical criteria, and metabolism as well as external and internal organs functions (Mohapatra et al., 2014; Surai, 2006). Supplementation of Se enhances the growth performance and antioxidant status of animals (Mahima et al., 2012). The Se can be added to the diets in the form of inorganic, organic, and nanoparticles; however, nanoparticles of $\mathrm{Se}$ (Nano-Se) have comparable efficiency, high bioavailability, strong adsorbing ability, and low toxicity 
compared with other Se sources (Wang et al., 2021). Nanotechnology offers an opportunity to mediate these issues as Nano-particles possess different physical and chemical properties than other forms of minerals Supplemented Nano-Se on growing rabbits at $50 \mathrm{mg} / \mathrm{kg}$ significantly increased growth performance and carcass criteria of rabbits compared to control (Sheiha, 2020). The selenium levels in the rabbit diets ranged from 0.05 to $0.4 \mathrm{mg} / \mathrm{kg}$ in non-supplemented to about $1 \mathrm{mg}$ with supplementation of $0.6 \mathrm{mg}$ selenium yeast or $0.6 \mathrm{mg}$ sodium selenite $/ \mathrm{kg}$ diet (Abdulrashid and Juniper, 2016; Amer et al., 2018; De Blas and Mateos, 2010; NRC, 1977; Abdel-Wareth et al., 2019). Since there are almost unlimited possibilities concerning the dosage of Se there is still more research needed. This review gives an overview of the mode of action, recommendation levels of Nano-Se, and its effects on growth performance, nutrient digestibility, carcass criteria, and blood biochemical metabolic profile of rabbits.

\section{The mode of action Selenium}

Limited literature is available regarding the mode of action effects of Nano-particles in rabbit nutrition. Response of rabbits performances are shown in figure1. Nanoparticles have higher physical activity and chemical neutrality. Bioavailability can be enhanced by increasing the surface area of respective minerals by making their Nanoparticles. Owing to the potential advantages of Nano-particles, interest in exploring their potential use and efficacy in animal production has increased significantly in this decade (Hassan et al., 2019). Nano-particles are one of the most innovative technologies to produce materials and different elements with changes in texture, structure, and enhanced quality at the molecular level (Usama, 2012). This technology is contributing significantly to the production, processing, storage, transportation, traceability, security, and safety of food (Otles and Yalcin, 2008). Trace elements like Se with potent antioxidant potential possess wide applicability as feed additives to alleviate oxidative stress in living systems (Hassan et al., 2019). Selenium plays a major role in antioxidative mechanism, male reproduction, thyroid metabolism, muscle development, and anti-carcinogenesis (Rayman, 2005). Nano-Se results in higher Se retention and glutathione S-transferase activity due to its smaller size and higher bioavailability (Peng et al., 2007). Recently, a possible mechanism for the conversion of Nano-Se to selenite has been proposed in monogastric animals suggesting that gut microbes can convert Nano-Se into selenite, Se-phosphate, or H2Se ultimately leading to the synthesis of selenoproteins (Surai et al., 2017).

The nanoparticle affects the cellular intake and allows them to easily pass through the stomach wall and diffuse into body cells quicker than common elements with larger particle sizes. The in vitro absorption of nanoparticles with a diameter of $0.1 \mu \mathrm{m}$ was found to be higher than 1 and $10 \mu \mathrm{m}$ nanoparticles (Desai et al., 1997). Nanoparticles especially nanomaterials of Se and $\mathrm{Zn}$ have a higher surface-area-tovolume ratio, providing more surface area for contact with the mucosal tissues and cells. Better absorption of nanoparticles into the mucosal surface increases the particle residence time in the gut. When a Nano mineral is introduced into a biological medium, such as blood or mucus, proteins adsorb on its surface, giving it a unique "biological identity", which may have an impact on the nanoparticles' distribution as well as their potential toxicity (Abdelnour et al., 2021). Moreover, this study will serve as a brainteaser for further investigation to explore the mode of action of Nano-Se and its optimal levels for increasing product performance and intestinal integrity while reducing intestinal permeability. 


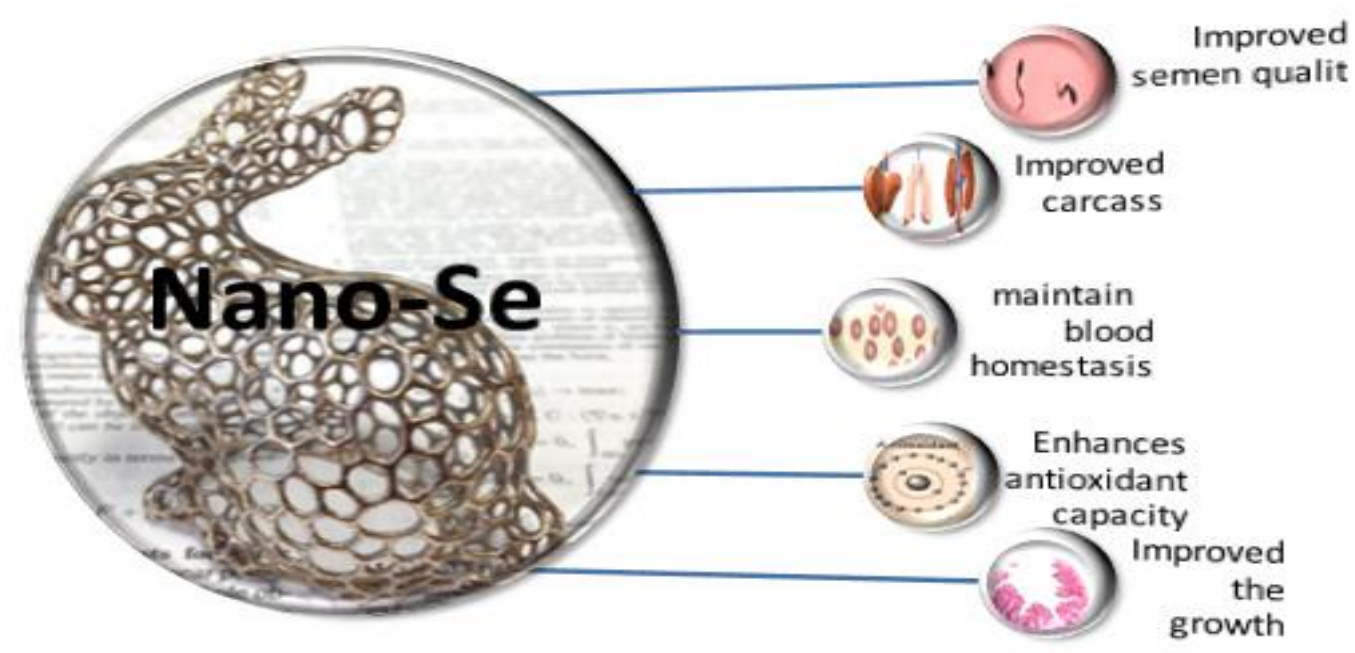

Figure 1. Response of rabbits to Nano-Se supplementations

Based on the studies mentioned above, NanoSe supplementation can have many health benefits such as improved production performance, growth, feed efficiency, antioxidant status, and immune status, when present in rabbit diets compared to inorganic Se sources. Nevertheless, high doses of NanoSe can cause the hyperaccumulation of $\mathrm{Se}$ in tissues and oxidative stress or toxicity. Therefore, Nano-Se should be included in rabbit diets in optimum doses to formulate nutritionally balanced feeds. The mechanism of Nano-Se conversion remains unclear, and the gut microbiota is thought to play a key role in this process. The application of Nano-Se showed promising results in enhancing the oxidative status of the cell induced by a reduction in glutathione and superoxide dismutase levels (Hassanin et al., 2013). NanoSe was likely employed in various researches as a ROS scavenger to protect against the oxidative damage in cells' sperm.

The affirmative result of Nano-Se administrations on semen traits could be owing to the possible role of these minerals as a co-factor in the activities of several antioxidant enzymes and the protective functions against reactive oxygen species. The increase in blood antioxidant minerals is usually associated with particular improvements in the antioxidant status of animals and, thus, the health status of animals. Nano-Se increased serum Se and superoxide, catalase, and glutathione peroxidase compared with provided $\mathrm{Se}$ yeast and sodium selenite (Shi et al., 2011).

The Se is an important dietary micronutrient required for the normal body functions and metabolism of animals (Keen et al., 2004) it plays a significant role in the catalytic processes within the enzyme system that consists of a variety of enzyme activities linked with the metabolic, endocrine, and immune systems. Supplementation of Se prevents cell damage and plays an important role in the development, fertility, and immune functions of humans and other vertebrates, including fish (Hoffmann and Berry, 2008), maintenance of growth, health, and some biochemical metabolic profile (Edens and Sefton, 2016). Dietary organic Se supplementation in postpartum mice enhanced Se deposition in the liver, blood, and mammary gland (Wang et al., 2021). Trace elements play an essential role in animal diet. Selenium is one of the critical nutritional factors necessary for the normal functioning of the immune system (Sharadamma et al., 2011). 
Selenium generally acts as a co-factor in an animal's body and is an essential part of many enzymatic chemical structures (selenoproteins). Glutathione peroxidase is the first selenoprotein identified in physiological systems with antioxidant activities (Back, 2013). Selenium plays a major role in antioxidative mechanism, male reproduction, thyroid metabolism, muscle development, and anti-carcinogenesis (Rayman, 2005). Nano-Se has also been shown to enhance the antioxidant capacity of the liver by reducing the amount of oxidized GSH-Px in the liver while increasing reduced GSH-Px levels. However, the reverse was observed in the case of their respective levels in the blood (SalahEldin et al., 2015). Recently, an exciting study reported significant improvement in gut health of birds fed with a medium dose of Nano-Se at $0.9 \mathrm{mg} / \mathrm{kg}$ by increasing the abundance of beneficial bacteria and production of butyric acid along with other short-chain fatty acids. This shows the potential of Nano-Se to modulate the gut microbiome to directly influence the immune system, intestinal health, and integrity as well as served as a brainteaser for further investigation to explore the potential of optimal Nano-Se levels for increasing intestinal integrity while reducing intestinal permeability (Hassan et al., 2020). Functions of proteins expressed indicated that a higher dose of Nano-Se supplementation induced dietary stress at the cellular level altering the carbohydrate and fatty acid metabolism (Peng et al., 2007). Nano-Se has higher bioavailability and relatively low toxicity compared to other selenium forms (Suchy et al., 2007). The Se can be supplemented in the form of organic, inorganic, and nanoparticles; however, nanoparticles of selenium possess comparable efficiency, high bioavailability, high catalytic efficiency, strong adsorbing ability, and low toxicity compared with other selenium sources (Wang et al., 2021). Selenium improves the productive performance and antioxidant status of animals (Mahima et al., 2012).

\section{The recommendation levels of $\mathrm{Se}$ in rabbit diets}

The Se levels in the rabbit diets vary widely according to dietary ingredients and $\mathrm{Se}$ supplementation, ranging from 0.05 to 0.4 $\mathrm{mg} / \mathrm{kg}$ in non-supplemented to about $1 \mathrm{mg}$ with supplementation of $0.6 \mathrm{mg}$ Se yeast or $0.6 \mathrm{mg}$ sodium selenite/kg diet (Abdulrashid and Juniper, 2016; Amer et al., 2018; De Blas and Mateos, 2010; NRC, 1977; Saleh et al., 2013; Strucklec et al., 1994; Zhang et al., 2011). Also, Din and Noha (2019) recommended that supplemented 0.1 and 0.3 $\mathrm{mg} \mathrm{Nano-Se} / \mathrm{kg}$ and $30 \mathrm{mg} / \mathrm{kg}$ and $60 \mathrm{mg} / \mathrm{kg}$ Nano-ZnO on growing rabbit diets improved rabbit performances. Al-Khafaji and Ibrahim (2019) recommended that supplemented $2 \mathrm{mg} / \mathrm{kg}$ and $3 \mathrm{mg} / \mathrm{kg}$ Nano-Se and $1.5 \mathrm{mg} / \mathrm{kg}$ Nano-Se $+150 \mathrm{mg}$ VE) on growing rabbits' diets improved rabbit performances. Emara (2019) recommended that supplemented intera muscularly injected once a week $4 \mathrm{ml}$ solution of Nano-Se on growing rabbit's diets improved rabbit performances. Furthermore, AbdelWareth et al. (2019) recommended that supplemented $400 \mu \mathrm{g} / \mathrm{kg}$ Nano-Se with or without $700 \mathrm{mg} / \mathrm{kg}$ garlic oil on growing rabbit diets significantly improved rabbit performances. Abd Allah et al (2020) recommended that supplemented $0.3 \mathrm{mg} 0.3$ $\mathrm{mg}$ Nano-Se/ $\mathrm{kg}$ and+ $0.3 \mathrm{mg}$ Nano-Se $/ \mathrm{kg}+$ $250 \mathrm{mg}$ Vit.E/ $\mathrm{kg}$ on growing rabbit's diets improved rabbit performances. Sheiha (2020) recommended that supplemented 25 and 50 $\mathrm{mg}$ of Nano-Se $/ \mathrm{kg}$ and $\mathrm{CH} 25$ and $\mathrm{CH} 50$, with 25 and $50 \mathrm{mg}$ of Nano-Se $/ \mathrm{kg}$ on growing rabbit diets improved rabbit performances. Qin et al. (2016) recommended that supplemented $0.3 \mathrm{mg} / \mathrm{kg}$ Nano-Se to growing rabbit's diets improved rabbit performances.

\section{Body weight and body weight gain:}

Supplemented Nano-Se to growing rabbits diets at 0.1 and $0.3 \mathrm{mg}$ Nano-Se/kg revealed that Nano-Se significantly increased BW and BW gain of rabbits compared with control (Din and Noha, 2019). Moreover, Mahmoud et al., (2016) reported that supplemented Nano- 
Se to growing broilers diets at $0.3 \mathrm{mg} / \mathrm{kg}$ resulted in Nano-Se significantly improved BW and BW gain of broilers compared with control. Al-Khafaji and Ibrahim (2019) found that supplemented Nano-Se to growing broilers diets at $1 \mathrm{mg} / \mathrm{kg}$ and $2 \mathrm{mg} / \mathrm{kg}$ and 3 $\mathrm{mg} / \mathrm{kg}$ revealed that Nano-Se significantly improved $\mathrm{BW}$ and $\mathrm{BW}$ gain of rabbits compared with control. Supplemented NanoSe to growing rabbits significantly increased BW and BW gain of rabbits compared with control (Emara, 2019). Furthermore, supplemented Nano-Se significantly improved BW and BW gain of broilers compared with control (Saleh and Ebeid, 2019; Ibrahim et al., 2020). Also, Abd Allah et al., (2020) reported that supplemented $0.3 \mathrm{mg} / \mathrm{kg}$ Nano-Se to growing rabbits diets significantly improved BW and BW gain of rabbits compared with control. Abdel-Wareth et al. (2019) reported that supplementation of Nano-Se at $400 \mu \mathrm{g} / \mathrm{kg}$ with or without $700 \mathrm{mg} / \mathrm{kg}$ garlic oil significantly improved $\mathrm{BW}$ and $\mathrm{BW}$ gain and BW and BW gain of rabbits compared with control. Addition of ad 25 and $50 \mathrm{mg}$ of Nano$\mathrm{Se} / \mathrm{kg}$ ) significantly increased $\mathrm{BW}$ and $\mathrm{BW}$ gain of rabbits compared with control (Sheiha, 2020).

\section{Feed intake and feed conversion ratio:}

Supplementations of Nano-Se at 0.1 and 0.3 $\mathrm{mg} / \mathrm{kg}$ and Nano-ZnO at $30 \mathrm{mg} / \mathrm{kg}$ and 60 $\mathrm{mg} / \mathrm{kg}$ to growing rabbits diets at (significantly improved feed intake and feed conversion ratio of rabbits compared with control (Din and Noha, 2019). Mahmoud et al. (2016) demonstrated that the addition of $0.3 \mathrm{mg} / \mathrm{kg}$ of Nano-Se to growing broilers diets significantly improved feed intake and feed conversion ratio of broilers compared with control. Supplementations of Nano-Se with or without vitamin E significantly improved feed intake and feed conversion ratio of rabbits compared with control (Al-Khafaji and Ibrahim, 2019). Feed intake and feed conversion ratio of growing rabbits were significantly improved by supplementation of Nano-Se compared with control (Emara, 2019).
Supplemented Nano-Se to the rabbit diets significantly improved feed intake and feed conversion ratio of broilers compared with control (Saleh and Ebeid, 2019; Ibrahim et al., 2020). Sheiha (2020) demonstrated that supplemented Nano-Se to growing rabbits at 25 and $50 \mathrm{mg} / \mathrm{kg}$ significantly improved feed intake and feed conversion ratio of rabbits compared with control. Nano-Se supplementation may be led to the improvement in growth performance of growing rabbits by increasing the final body weight and daily gain in the growing rabbits. Such as supplemented Nano-Se at $400 \mu \mathrm{g} / \mathrm{kg}$ with or without $700 \mathrm{mg} / \mathrm{kg}$ garlic oil to rabbit diets significantly improved feed intake and feed conversion ratio of rabbits compared with control (Abdel-Wareth et al., 2019).

\section{Blood biochemistry:}

An increase of total protein by Nano-Se (0.3 $\mathrm{mg} / \mathrm{kg}$ ) diet may be due to Se can improve plasma lipoproteins i.e. decline the LDL, HDL, cholesterol, and plasma triglycerides (lizuka et al., 2001). Shunyi et al. (2016) reported that blood total protein was not significantly affected by Nano-Se supplementation to growing rabbit's diet. Shunyi et al. (2016) reported that the blood biochemistry of rabbits, including concentrations of cholesterol, HDL, and triglyceride were not significantly affected by supplementation of Nano-Se or sodium selenite. Also, Shunyi et al. (2016) reported that the blood biochemistry of rabbits, including concentrations of alanine aminotransferase (ALT) and aspartate aminotransferase (AST) were not significantly affected by supplementation of Nano-Se or sodium selenite. Furthermore, Se is known to have important roles in reproductive functions and development, immunocompetence, and aging. The Se is an essential trace mineral and has a profound effect on performance and immunity. The Se and vitamin E deficiency together in poultry causes exudative diathesis, pancreatic dystrophy, and nutritional muscular dystrophy. The Se is also, an integral part of 
the enzyme known as glutathione peroxidase which is involved in the cell antioxidant defense mechanism and prevents the cells from free radical damage McDowell (1992). On the other hand, Mohapatra et al. (2014) found that liver enzymes were insignificantly influenced by Nano-Se $(0.15,0.30$, and 0.60 ppm) supplementation compared with the control. Selim et al. (2015) found that increasing supplemental Nano-Se level from 0.15 to $0.30 \mathrm{ppm}$ in broiler diets resulted in an increase in plasma creatinine level compared with the control group without any significant differences.

Qin et al. (2016) reported that supplemented Nano-Se at $0.3 \mathrm{mg} / \mathrm{kg}$ Nano-Se and $0.3 \mathrm{mg} / \mathrm{kg}$ to growing rabbits diets significantly improved total protein, AST, and ALT of rabbits compared with control. Also, Din and Noha (2019) showed that Nano-ZnO and Nano-Se significantly improved total protein, cholesterol, AST, ALT albumin, globulin, urea, and creatinine of growing rabbits compared with control. Shokraneh (2019) reported that Nano-ZnO and Nano-Se significantly improved, ALT, AST, triglycerides, superoxide dismutase, glucose, cholesterol, and total protein of broiler compared with control. Supplemented NanoSe at $400 \mu \mathrm{g} / \mathrm{kg}$ with or without $700 \mathrm{mg} / \mathrm{kg}$ garlic oil significantly improved liver and kidney functions of rabbits compared with control. Likewise, Sheiha (2020) found that Nano-Se significantly enhanced liver and kidney functions of rabbits compared with control. Saleh and Ebeid (2019) indicated that Nano-Se significantly improved glucose, AST, ALT, triglycerides, superoxide dismutase, and cholesterol of broilers compared with control. Nano-Se significantly decreased triglycerides, superoxide dismutase, and malondialdehyde of rabbits compared with control (Sheiha, 2020). Nano-Se significantly increased the Red Blood cells and White Blood cells of broilers compared with control (Ibrahim et al., 2020).

\section{Carcass characteristics:}

Nano-ZnO and Nano-Se significantly increased carcass criteria, kidneys, heart, liver, and head of rabbits compared with control (Din and Noha, 2019). Saleh and Ebeid (2019) reported that Nano-Se significantly improved carcass traits and decreased internal organs of broilers compared with control.

Nano-Significantly improved kidneys, liver muscles, and blood serum of rabbits compared with control (Abd Allah et al., 2020). In ovo injection of Nano-Se did not affect ( $\mathrm{P}>$ 0.05) carcass, breast, thigh, totally edible, heart, gizzard, liver, spleen, thymus, bursa of broilers compared with control (Ibrahim et al., 2020). Sheiha (2020) found that Nano-Se significantly increased carcass liver, heart, lungs, kidneys, and spleen of rabbits compared with control.

\section{Conclusion}

It can be concluded that the levels of Se in the rabbit diets vary widely according to dietary ingredients and Se supplementation, ranging from 0.05 to $2.0 \mathrm{mg} / \mathrm{kg}$ diet. Supplementation of Nano-Se improved growth performance, nutrient digestibility, carcass criteria, blood biochemical of rabbits. Since there are almost unlimited possibilities concerning the dosage of Se there is still more research needed.

\section{References}

Abd Allah, D., Tawfeek, M., El Kerdawy, A. (2020). 'Impact of dietary supplementation with nano and organic selenuim without or with vitamin e on growth performance and selenium metabolism in growing rabbits', Journal of Productivity and Development 25, pp, 323-342.

Abdel-Wareth, A.A.A., Hassan, H., Abd ElSadek, M., Ghazalah, A., Lohakare, J. (2019). 'Nutritional impact of nanoselenium, garlic oil, and their combination on growth and reproductive performance of male Californian rabbits', Animal Feed Science and Technology 249, pp, 37-45. 
Al-Khafaji, F.R., Ibrahim, M.K. (2019). 'The effectiveness of nano-selenium and vitamin e added to the diet in improving the productive efficiency for broiler chickens exposed to thermal stress' Plant Archives 19, pp, 1239-1246.

Arshad, M.A., Ebeid, H.M., Hassan F.-U. (2021). 'Revisiting the effects of different dietary sources of selenium on the health and performance of dairy animals: a review'. Biological Trace Element Research 199, pp, 3319-3337.

Back, T.G. (2013). 'Investigations of new types of glutathione peroxidase mimetics. Biochalcogen Chem: the biological chemistry of sulfur, selenium and tellurium'. Chapter 7 ACS Symposium Series 1152, pp, 143-162.

Boostani, A., Sadeghi, A., Chamani, M., Kashan, N. (2014). 'The Effects of Organic, Inorganic and Nano-Selenium on Blood Thyroid Hormones Concentration in Broiler Chickens Exposed to Oxidative Stress'. Life Science 3, pp, 146-149.

Cai, S., Wu, C., Gong, L., Song, T., Wu, H., Zhang, L. (2012). 'Effects of nanoselenium on performance, meat quality, immune function, oxidation resistance, and tissue selenium content in broilers'. Poultry Science 91, pp, 2532-2539.

Din, T.-E., Noha, T. (2019). 'Effects of dietary nano-zinc and nano-selenium addition on productive and physiological performance of growing rabbits at fattening period' Egyptian Journal of Nutrition and Feeds, 22(1), pp, 79-89.

Edens, F.W., Sefton, A.E. (2016). 'Organic selenium in animal nutrition-utilisation, metabolism, storage and comparison with other selenium sources'. J. Appl. Anim. Nutr., 4, pp, e9.

El-Badry, A., Hassanane, M.M., Mosalm, G., Ahmed, E.S., El-Aasar, T. (2019). 'Influence of ingestion of nano-selenium on growth performance, antioxidative and mutagenicity status in somatic cells of New Zealand White rabbits'. Egyptian Journal of Rabbit Science 29, pp, 1-21.

Emara, S.S. (2019). 'Comparative Effects of nano-selenium and sodium selenite supplementation on blood biochemical changes in relation to growth performance of growing New Zealand White Rabbits'. Arab Journal of Nuclear Sciences and Applications 52, pp, 1-14

Ghaderzadeh, S., Aghjeh-Gheshlagh, F.M., Nikbin, S., Navidshad, B. (2016).

Review on properties of selenium in animal nutrition'. Iranian Journal of Applied Animal Science 6, pp, 753-761.

Gouda, N., El Kelawy, H., Abd El Rahim, M., El-Gaafary N., Ibrahim, H. (2021). 'Effect of treatment with nano-se and vitamin e on semen quality and some blood parameters of buck rabbits'. Journal of Productivity and Development 26, pp, 903-922.

Hashem, N.M., Gonzalez-Bulnes, A. (2020). State-of-the-art and prospective of nanotechnologies for smart reproductive management of farm animals'. Animals, 10,840 .

Hassanin, K.M., Abd El-Kawi, S.H.,Hashem, K.S. (2013). 'The prospective protective effect of selenium nanoparticles against chromiuminduced oxidative and cellular damage in rat thyroid'. Int. J. Nanomed., 8, pp, 1713-1720.

Hoffmann, P.R., and MJ. Berry. (2008). 'The influence of selenium on immune responses. Molecular Nutrition and Food Research', 52, pp, 1273-1280.

Horky, P., Ruttkay-Nedecky, B., Nejdl, L., Richtera, L., Cernei, N., Pohanka, M., Kopel, P., Skladanka, J., Hloucalova, P., Slama, P., et al. (2016). 'Electrochemical Methods for Study of Influence of Selenium Nanoparticles on Antioxidant Status of Rats'. Int. J. Electrochem. Sci. 2016, 11, pp, 2799-2824.

Hu, C., Li, Y., Xiong, L., Zhang, H., Song, J., Xia M. (2012). 'Comparative effects of nano elemental selenium and sodium selenite on selenium retention in broiler 
chickens'. Animal feed science and technology 177, pp, 204-210.

Ibrahim, N., Sabic, E., Wakwak, M., ElWardany, I., El-Homosany, Y., Mohammad, N.E.D. (2020). ' In-Ovo and dietary supplementation of selenium nano-particles influence physiological responses, immunological status and performance of broiler chicks'. Journal of Animal and Feed Sciences 29(1), pp, 46-58

Iizuka, Y., Sakurai, E., Tanaka, Y. (2001). 'Effect of selenium on serum, hepatic and lipoprotein lipids concentration in rats fed on a high cholesterol diet'. Yakugaku Zasshi: Journal of the Pharmaceutical Society of Japan, 121, pp. 93- 96.

Mahima, A.K., Amit, K., Anu, R., Vinod, K., Debashis, R., (2012). 'Inorganic versus organic selenium supplementation': a review. Pak. J. Biol. Sci. 15 (9),pp. 418 425.

Mahmoud, H.,E.D., D., Ijiri, T.A.,Ebeid, and A. Ohtsuka. (2016). 'Effects of dietary nano-selenium supplementation on growth performance, antioxidative status, and immunity in broiler chickens under thermoneutral and high ambient temperature conditions'. The Journal of Poultry Science 0150133.

Malyugina, S., S. Skalickova, J., Skladanka, P., Slama, and P., Horky. (2021). 'Biogenic Selenium Nanoparticles in Animal Nutrition: A Review'. Agriculture 11, pp. 1244.

Mohapatra, P., Swain, R.K., Mishra, S.K., Behera, T., Swain P., Behura, NC., Sahoo, G., Sethy, K., Bhol, B.P., Dhama, K. (2014). 'Effects of nanoselenium Supplementation on the performance of layer grower birds'. Asian Journal of Animal and Veterinary Advances, 9(10), pp. 641-652.

Mohapatra, P., Swain, R.K., Mishra, S.K., Behera, T., Swain, P., Behura, N.C., Sahoo, G., Sethy, K., Bhol, B.P., Dhama, K. (2014). 'Effects of nano-selenium
Supplementation on the performance of layer grower birds' Asian Journal of Animal and Veterinary Advances, 9(10), pp, 641-652.

Muktar, Y., Bikila, T., Keffale, M. (2015). Application of nanotechnology for animal health and production improvement: a review'. World Appl Sci J 33, pp, 1588-1596.

Nabi, F., Arain, M., Hassan, F., Umar, M., Rajput, N., Alagawany, M., Syed, S., Soomro, J., Somroo, F., Liu, J. (2020). 'Nutraceutical role of selenium nanoparticles in poultry nutrition: a review'. World's Poultry Science Journal 76, pp, 459-471.

Otles, S., Yalcin, B. (2008). 'Smart food packaging', Elektroniczne czasopismo naukowe z dziedziny logistyki 4, pp.1-7.

Peng, D., Zhang, J., Liu, Q. Taylor E.W. (2007). 'Size effect of elemental selenium nanoparticles (nano-Se) at supranutritional levels on selenium accumulation and glutathione Stransferase activity'. J Inorg Biochem 101:1457-1463.

Qin, F., Chen, F., Zhao, F.H., Jin ,T.M., Ma, J. (2016). 'Effects of Nanoselenium on Blood Biochemistry, Liver Antioxidant Activity and GPx-1 mRNA Expression in Rabbits'. In International Conference on Biomedical and Biological Engineering'. Atlantis Press. pp. 166171. https://doi. org/10.2991/bbe16.2016.

Rana, T. (2021). 'Nano-selenium on reproductio and immunocompetence: an emerging progress and prospect in the productivity of poultry research'. Tropical Animal Health and Production 53, pp, 1-7.

Rayman, M.P. (2005). 'Selenium in cancer prevention: a review of the evidence and mechanism of action', Proc Nutr Soc 64, pp. 527-542.

Rosa de Oliveira, G., de Andrade, C. Santos Sotomaior, C., Batista Costa, L. (2021). 
Advances in nanotechnology and the benefits of using cellulose nanofibers in animal nutrition'. Veterinary World 14.

Salah-Eldin, T.A., Hamady, G.A.A., AbdelMoneim, M.A., Farroh, K.Y., El-Reffaei W.H.M. (2015). 'Nutritional evaluation of seleniummethionine nanocomposite as a novel dietary supplement for laying hens'. J Anim Health Prod 3(3), pp. 6472.

Saleh, A., Ebeid, T. (2019). ' Feeding sodium selenite and nano-selenium stimulates growth and oxidation resistance in broilers'. South African Journal of Animal Science 49, pp.176-183.

Selim, N.A., Radwan, N.L., Youssef, F., Salah E.T.A., Abo Elwafa, S. (2015). ' Effect of Inclusion Inorganic, Organic or Nano Selenium Forms in Broiler Diets On:2Physiological, Immunological and Toxicity Statuses of Broiler Chicks'. International Journal of Poultry Science, 14(3), pp. 144-155.

Sharadamma, K.C., Purushotham, B., Radhakrishna, P.M., Abhilekha, P.M., Vagdevi, H.M. (2011). 'Role of selenium in pets health and nutrition: A Review'. Asian J. Anim. Sci. 5, pp. 64-70.

Sheiha, A.M., Abdelnour, S.A., El-Hack, A., Mohamed, E., Khafaga, A.F., Metwally, K.A., Ajarem, J.S., Maodaa, S.N., Allam, A.A., El-Saadony, M.T. (2020). 'Effects of dietary biological or chemical-synthesized nano-selenium supplementation on growing rabbits exposed to thermal stress'. Animals 10, pp. 430.

Shi, L., Xun, W., Yue, W., Zhang, C.,Ren, Y.,Shi, L., Wang, Q., Yang, R., Lei, F. (2011). 'Effect of sodium selenite, Seyeast and nanoelemental selenium on growth performance, Se concentration and antioxidant status in growing male goats'. Small Rumin. Res., 96, pp. 49-52.

Shunyi, Q., Fu, C., Fang, Z., Tianming, J.I., Jifei, M.A. (2016). 'Effects of Nanoselenium on blood biochemistry, liver antioxidant activity and GPX-1 MRNA expression in rabbits'. International Conference on Biomedical and Biological Engineering .

Suchy, P., Strakova, E., Herzig, I. (2014). 'Selenium in poultry nutrition: a review'. Czech J Anim Sci 59(11), pp. 495-503.

Surai, P.F., Kochish, I.I., Velichko, O.A. (2017). 'Nano-Se assimilation and action in poultry and other monogastric animals: is gut microbiota an answer?' Nanoscale Res Lett 12, pp. 612

Usama, T.M. (2012). 'Silver nanoparticles in poultry production', JAdv Vet Res 2, pp.303-306

Wang, Z.-N., Li, H.; Tang, H., Zhang, S.-J., Pauline, M., Bi, C.-L. (2021). Short Communication: 'Effects of Dietary Selenium Supplementation on Selenium Deposition and Antioxidant Status in Postpartum Mice. Biol'. Trace Elem. Res. 199, pp. 1488-1492. 
